\title{
ANALISA ROUTINE ACTIVITY THEORY DALAM PERDAGANGAN SEKS DI THAILAND, CHINA DAN VIETNAM
}

\author{
Yusnarida Eka Nizmi
}

Pengajar pada Jurusan IImu Hubungan Internasional

Fakultas IImu Sosial dan IImu Politik Universitas Riau

\begin{abstract}
ABSTRAK
Tulisan ini mengeksplorasi berbagai varian perdagangan seks untuk Eksploitasi Seks Komersil (CSE) dari sebuah perspektif global dengan fokus pada berbagai tujuan dan pada korban. Masing-masing kasus perdagangan seks di setiap wilayah memiliki keunikannya masing-masing, namun ada beberapa realita yang sama disetiap kasus perdagangan seks dalam perdagangan seks dengan korbannya perempuan dan anak-anak untuk tujuan eksploitasi seksual. Pertama, Kedua, isu-isu sosial termasuk pengabaian hak-hak perempuan dan menjadikan perempuan hanya sebagai objek, ketidaksetaraan gender menjadi persoalan yang melanda berbagai negara. Ketiga, olah raga dan dunia hiburan juga memperbesar peluang terjadinya perdagangan orang. Fakta menunjukkan telah terjadi peningkatan jumlah pekerja seks karena terlibat dalam retrafficking, dua, tiga kali bahkan lebih. Karena hampir semua korban yang melarikan diri dihadapkan kembali pada kondisi kemiskinan, kekerasan domestik, minimnya kesempatan ekonomi menyebabkan para penjual pekerja seks berhasil membuat kesepakatan untuk kedua- kalinya dengan para korban. Hal ini membuat para korban sulit untuk keluar dari lingkaran prostitusi. Para korban berhasil direkrut kembali oleh para penjual perempuan yang berbeda. Kemiskinan, bias gender, dan lemahnya penegakan hukum telah turut membantu kelancaran prostitusi.
\end{abstract}

Kata Kunci: Perdagangan orang, Perdagangan seks, Routine Activity Theory,Bias Gender

\section{PENDAHULUAN}

Perdagangan perempuan bukanlah sebuah fenomena baru. Sejak akhir abad kesembilan belas perdagangan orang khususnya perdagangan perempuan sudah menjadi persoalan internasional. Konsep mengenai apa sebenarnya yang dimaksud dengan perdagangan perempuan masih menjadi diskusi yang terus berlangsung. Mengulas konsep pedagangan orang memang menjadi hal yang cukup penting, tetapi yang lebih mendasar untuk diselesaikan adalah perempuan yang menjadi korban prostitusi tersebut.Banyak pengambil kebijakan masih memperdebatkan apa arti perdagangan orang yang sebenarnya. PBB, mengartikan perdagangan orang secara umum sebagai berikut (United States Department of State, 2007) : The recruitment, transportation, transfer, harbouring or receipt of persons by means of threat or use of force or other forms of coercion, of abduction, of fraud, of deceotion, of the abuse of power, or of a position of vulnerability or of the giving or receiving of payments or benefits to achieve the consent of a person having control over another person, for the purpose of exploitation. Exploitation shall include, at a minimum, the exploitation of prostitution of others or other forms of sexual exploitation, forced labour services, slavery or practices similar to slavery, servitude or the removal of organs. 
Vol 6, No 1, April 2011: $33-45$

Beberapa hal yang membingungkan terkait pemaknaan perdagangan orang oleh PBB, antara lain sebagai proses "rekrutmen, transportasi, dan transfer orang untuk tujuan eksploitasi”. Banyak aturan hukum dan program yang dibuat untuk melawan perdagangan orang hanya memfokuskan pada persoalan pergerakannya, bukan pada eksploitasinya. Dalam tulisan ini, perdagangan orang khususnya perdagangan perempuan bukan hanya sebatas persoalan pergerakan, tetapi juga mengenai pelacuran. Keberadaan pelacuran muncul melalui tiga cara. Pertama, melalui topeng tawaran pekerjaan ataupun gaji yang tinggi. Ketika orang merasa putus asa dengan kondisi ekonomi, maka, tawaran-tawaran pekerjaan di surat kabar harian selalu dapat dipastikan berhasil merekrut ribuan pekerja seks dengan janji-janji pekerjaan palsu di negara-negara tertentu. Perdagangan perempuan untuk pelacuran juga berjalan mulus karena tawaran-tawaran pernikahan palsu. Di negara-negara yang kehidupannya sangat sulit, perempuan-perempuan yang tidak menikah dan pernikahan menjadi satu-satunya cara bagi perempuan untuk mendapatkan kenyamanan, hak-hak dasar sebagai masyarakat, dan menghindari hinaan seumur hidup. Kedua, pelacuran terjadi karena dijual oleh keluarga sendiri. Kemiskinan, keputusasaan, dan ketiadaan pekerjaan menggiring banyak keluarga menjual anak dalam pelacuran. Ketiga, asmara. Banyak korban yang dipaksa terlibat dalam prostitusi karena bujukan asmara --- dan ketiga kondisi ini terdapat hampir di semua negara.

Dari berbagai persoalan terkait dengan perdagangan manusia yang menjadi kunci persoalan adalah defenisi perdagangan orang itu sendiri. Persoalan lain adalah tidak ada metode khusus dan resmi untuk mengumpulkan informasi terhadap kasus-kasus yang melibatkan anak-anak sebagai korban serta tidak ada satu pun departemen atau agensi di dunia yang khusus bertanggung jawab mengumpulkan data dan informasi perdagangan orang atau para pelaku perdagangan orang. Deklarasi Hak Asasi Manusia pada tahun 1948 dengan tegas menyatakan bahwa seluruh manusia dilahirkan bebas, dan tidak ada seorangpun yang terkurung dalam perbudakan, oleh karena itu, setiap orang memiliki hak untuk bebas termasuk bebas memilih pekerjaan; namun perdagangan orang mengabaikan hak-hak dasar tersebut. Pada akhirnya, perdagangan orang terutama untuk tujuan seks adalah masalah yang terjadi di hampir seluruh negara. Para korban perdagangan seks adalah pria, perempuan, dan anak-anak. Para korban ini mendapatkan paksaan berupa kekerasan fisik atau ancaman untuk melayani jasa seks demi keuntungan pihak-pihak yang memperdagangkan mereka.

\section{Perdagangan Seks}

Perdagangan seks adalah kejahatan serius terhadap kemanusiaan karena mendapatkan keuntungan dengan menghancurkan kehidupan perempuan. Para pekerja seks diambil dari negara asalnya dan diselundupkan melalui negara-negara transit menuju negara-negara tuju (Kwong, 2001). Bisnis seks kontemporer melibatkan eksploitasi yang 34 
Analisa Routine Activity Theory dalam Perdagangan Seks di Tahiland, China dan Vietnam

(Yusnarida Eka Nizmi)

sistematis. Eksploitasi terhadap pekerja seks terutama diindikasikan dengan adanya kekerasan dan tidak membayar jasa servis seks. Para korban pelacuran terbiasa mengalami pemerkosaan, penyiksaan, kelaparan, bahkan pembunuhan, juga secara langsung atau tidak langsung mengakibatkan penularan penyakit seksual dan pemakaian psikotropika. Oleh karena itu, hukum dihampir semua negara melawan perkosaan, penyiksaan, sehingga hukuman yang ditegakkan lebih teraplikasi dengan baik dibandingkan dengan hukum terkait perlawanan terhadap perdagangan seks. Bagi korban perdagangan seks, melarikan diri adalah pilihan yang sangat jarang mereka lakukan. Para korban bahkan tidak berani berusaha melarikan diri karena para pemilik prostitusi tidak hanya mengancam dan mengintimidasi korban, tetapi juga keluarganya.

Perdagangan seks adalah bisnis yang sangat menguntungkan dan melibatkan terkait erat dengan perabatasan-perbatasan nasional. Perdagangan seks merupakan kejahatan kriminal ketiga yang sangat menguntungkan setelah perdagangan obat dan senjata, dimana telah diidentifikasi lebih dari 150 negara para korbannya 80 persen adalah kaum perempuan. Tidak terkecuali China, Thailand, dan Vietnam.

Untuk menganalisa persoalan seks trafficking, analisa yang paling mendekati untuk memahami persoalan kejahatan kemanusiaan ini adalah dengan memahami Routine Activity Theory (Currant and Renzetti, 2001, 43-47) bahwa kejahatan akan muncul ketika tiga faktor utamanya ada yakni: (1) ada motif dari pihak penyerang (2) target yang sangat sesuai (3) ketiadaan pengawal yang kompeten. Dalam bab ini, yang dimaksud dengan para penyerang adalah Para Gengster Asia Timur, target yang sesuai adalah kaum perempuan yang dengan mudah direkrut oleh para pelaku perdagangan seks dikarenakan kondisi kemiskinan ekonomi dan ketiadaan para pengawal yang kompeten mengacu pada minimnya penegakan hukum dalam melawan para pelaku perdagangan orang baik dari negara-negara Asia maupun Barat (termasuk Amerika Utara).

Bisnis perdagangan seks, sangat mengedepankan keuntungan. Hal ini sangat disadari oleh para penyerang (pelaku perdagangan orang untuk tujuan seks) menurut teori routine activity, dan cara yang paling effektif dalam bisnis apapun untuk meningkatkan laba keuntungan adalah dengan meminimalisir biaya pengeluaran (Mill, 2004). Hampir semua bisnis, biaya pengeluaran terbesar adalah membayar gaji tenaga kerja. Bayangkan kalau rumah pelacuran dianggap sebagai bisnis, maka, pemilik rumah pelacuran tidak akan dipusingkan dengan pembayaran upah tenaga kerja mereka karena klien tenaga kerjanyalah yang membayar upahnya. Pemilik rumah pelacuran dapat dikatakan tidak membayar apapun terhadap tenaga kerjanya.

Ketiadaan perlindungan hukum, khaos, ketidakmampuan melindungi hak-hak dasar individu, menggiring terjadinya peningkatan pelacuran yang berujung pada peningkatan keuntungan pada bisnis pelacuran. Semakin besar keuntungan yang didapat, maka, 
Vol 6, No 1, April 2011: $33-45$

semakin besar permintaan terhadap pekerja seks. Semakin besar permintaan, maka, semakin potensiallah pasar bagi produk-produk pelacuran. Semakin murah ongkos seks, semakin banyak pria yang mampu membayar, maka, akan semakin seringlah ia membayar untuk kelanggengan bisnis yang menghancurkan kehidupan para perempuan itu. Elastisitas permintaan ini menggiring pada sisi penawaran pelacuran.

\section{METODE PENELITIAN}

Penelitian ini mempergunakan metode kualitatif yaitu dengan studi literatur (library research). Pengumpulan data-data dan dokumen pendukung untuk menganalisis penelitian ini penulis dapatkan dari jurnal, buku-buku, laporan tahunan yang terkait dengan penelitian ini yang memfokuskan pada analisis Routine Activity Theory yang terjadi di Thailand, China dan Vietnam.

\section{HASIL DAN PEMBAHASAN}

\section{Perempuan-Perempuan Asia yang Potensial}

Banyak penelitian mengenai perdagangan seks lebih terfokus pada korban-korban dari Asia. Faktanya, banyak liputan surat kabar, studi-studi kasus, dan studi empiris perdagangan seks tidak hanya berasal dari perempuan-perempuan dan anak-anak Asia. Tulisan ini akan dibagi menjadi dua sesi; sesi pertama adalah pembahasan yang fokus pada China, Thailand dan Vietnam dan sesi lainnya adalah upaya Thailand untuk mengatasi persoalan perdagangan seks dan juga faktor-faktor apa saja yang berkontribusi terhadap perdagangan seks.

Dari hasil penelitian yang dilakukan oleh beberapa peneliti diketahui bahwa di wilayah Asia Timur dan Pasifik, perdagangan seks muncul karena dipengaruhi oleh sindikat kejahatan yang terorganisir yang melindungi para korban tidak hanya untuk sementara waktu namun juga pemenuhan segala kebutuhan para korban dengan konsekwensi menjadi pekerja seks tetap, khususnya anak-anak korban perdagangan seks. Diketahui juga dari hasil penelitian bahwa anak-anak yang terlibat dalam perdagangan seks komersil biasanya terhubung dengan media internet dan ruangan khusus untuk mengidentifikasi korban yang potensial dan sama halnya dengan yang dilakukan Amerika Serikat, mengawasi media internet adalah sebuah usaha yang harus dilakukan untuk mengidentifikasi para penjual orang.

Sama halnya dengan China, sebagaimana yang dilaporkan oleh PBB pada tahun 2006, bahwa keterlibatan sindikat kejahatan terorganisir sangat berpengaruh dalam kasuskasus perdagangan seks (UNODC, 2006). Struktur sindikat ini sangat terorganisir dengan baik dengan tingkatan kewajiban dan tanggung jawab yang berbeda pula, dan sindikat- 
Analisa Routine Activity Theory dalam Perdagangan Seks di Tahiland, China dan Vietnam

(Yusnarida Eka Nizmi)

sindikat ini sangat rinci dan detail dalam mengidentifikasi dan menetapkan para targetnya untuk terlibat dalam perdagangan seks.

Thailand dikenal sebagai negara asal bagi tenaga kerja California, pada tahun 1996 mencuat kasus Amerika Serikat versus Manusurangkun, yang diidentifikasi sebagai negara asal perdagangan seks. Pemerintah Thailand memperkirakan ada sekitar 250,000 pekerja seks yang bekerja di seluruh wilayah Thailand setiap tahunnya. Tentu saja banyak korban perdagangan seks di Thailand adalah penduduk asli Thailand, meskipun banyak juga yang berasal dari luar Thailand. Sayangnya, undang-undang immigrasi Thailand menyatakan bahwa para korban perdagangan seks yang bukan berasal dari Thailand justru tidak menerima bantuan yang diperuntukkan bagi para korban.

Negara Vietnam menerima banyak kritikan dari warga Amerika Serikat dan Eropa karena ketidakjelasan undang-undang tenaga kerja Vietnam khususnya udang-undang yang mengatur regulasi dan penyimpangan yang dilakukan oleh para bos terhadap para pekerjanya. Terkait dengan perdagangan tenaga kerja, Vietnam memberikan wewenang terhadap para perusahaan untuk mengawasi operasional mereka sendiri yang sangat memberi ruang untuk terjadinya penyimpangan tidak hanya pada tingkat nasional tetapi tingkat internasional, seperti penyimpangan kontrak kerja menjadi pekerja seks di Amerika Serikat (McCabe, 2008). Sebagaimana telah didiskusikan pada bab sebelumnya, bahwa kaum perempuan dan anak-anak, yang sangat ingin lari dari kemiskinan yang melanda negaranya, akan meninggalkan Vietnam menuju Eropa dan Jepang dan dengan sangat mudah menjadi target korban-korban baru bagi perdagangan seks.

Selama beberapa tahun di abad 21, Taiwan dikelompokkan dalam Tier 2 karena pemerintahnya berupaya untuk mencegah perdagangan orang. Namun sejak tahun 2005, penegakan hukum dan NGO-NGO di Taiwan mencatat terjadinya peningkatan jumlah korban perdagangan seks baik nasional maupun internasional yang menyebabkan turunnya klasifikasi Taiwan menjadi negara yang tidak mampu melakukan upaya pencegahan terhadap terjadinya perdagangan seks. Penjelasan mengapa Taiwan mengalami penurunan klasifikasi Tier mereka terkait dengan apa yang disebut Amerika Serikat dengan fenomena pengantin pesanan melalui email, McCabe (2007) menyebutnya dengan pasangan pengantin prostitusi, dan pemanfaatan media internet merupakan cara untuk menjaring para korban masuk dalam perdagangan seks.

Dari 2003 sampai dengan 2007, Departemen Luar Negeri Amerika Serikat melaporkan bahwa lebih dari 7,000 kasus perdagangan seks terjadi di Asia Timur dan wilayah Pasifik. 16 undang-undang baru atau peraturan yang telah diamandemenkan kerap diabaikan dalam mengatasi persoalan perdagangan orang di wilayah tersebut. Tulisan ini tidak hanya mendiskusikan mengenai faktor-faktor yang memfasilitasi terjadinya 
perdagangan seks namun juga kejahatan terorganisir yang terkait dengan kasus-kasus perdagangan seks yang terjadi di wilayah Asia Timur dan Pasifik.

\section{Keterlibatan Geng-Geng Asia, Si- Para Penyerang}

"Kelompok kejahatan terorganisir" diidentifikasikan sebagai: sebuah kelompok yang terstruktur yang terdiri dari 3 orang atau lebih, memiliki tujuan pada sebuah kejahatan serius baik terlibat secara langsung maupun tidak untuk mendapat keuntungan finansial maupun keuntungan yang lain. Criminal Intelligence Service of Canada (CISC) mengamati bahwa para gengster Asia tidak hanya sesuai dengan defenisi ini, namun juga mempraktekkan “ kepatuhan dan fleksibilitas struktural" (Helfand, 2003).

McCabe (2008) menyatakan bahwa, jaringan kejahatan kriminal yang terlibat dalam perdagangan orang merupakan sebuah pola yang sangat teratur antar anggota satu dengan yang lainnya. Costa Nostra, diorganisir mirip seperti struktur piramida yang harusnya memudahkan penegakan hukum bagi para anggota sampai ke level tertinggi, namun kelompok kejahatan Asia justru diorganisir dengan pola piramida-piramida mini, dengan divisi-divisi dan bos-bos kecil yang mengatur segala kegiatan hanya di divisi mereka sendiri. Lebih mengejutkan karena kelompok kejahatan terorganisir ini juga termasuk mereka yang bekerja dalam biro-biro perjalanan, baik domestik maupun internasional. Kelompokkelompok ini secara intensif melibatkan remaja dan dan geng-geng jalanan tidak hanya sebagai pekerja mereka namun untuk memperluas aktivitas kejahatan mereka. Federal Bureau of investigation (FBI) melaporkan bahwa perdagangan seks yang ditujukan ke Amerika Serikat dikontrol oleh para gengster dari empat wilayah Asia Timur yakni: China, Jepang, Vietnam dan Thailand. Bab ini akan memfokuskan pada kelompok gang yang berasal dari China, Thailand dan Vietnam.

\section{Triad-Triad China}

China diidentifikasi sebagai sumber, transit dan negara tujuan perdagangan seks. Sejak tahun 2001, kecuali pada tahun 2007 ketika China tidak dirangking, China dikelompokkan pada kategori Tier 2 atau Tier 2 Watch List. Dapat dipastikan, banyak kasus perdagangan orang di China melibatkan gang-gang kriminal; oleh karena itu, sangat sulit untuk mendeteksinya. Faktanya, seluruh gang-gang kriminal yang menjalankan industri perdagangan seks menjadi anggota Triad China.

Pergerakan Triad didirikan pada tahun 1600-an dengan tujuan memajukan dinasti Manchu Ching dan merestorasi dinasti Ming (Song and Dombrink, 1994). Kata "triad" berasal dari bahasa Inggris yang menggambarkan segitiga dengan indikasi tiga kekuatan utama secara universal yakni- surga, bumi, dan manusia. Secara filosofinya, kondisi-kondisi dari surga dan bumi memfasilitasi suksesnya seorang manusia. Saat ini, Triad juga berkembang di Amerika Serikat, Kanada, Hong Kong, Malaysia, Singapura, Thailand, Burma dan Taiwan yang secara aktif memang terlibat dalam aktivitas-aktivitas kejahatan kriminal. 
Analisa Routine Activity Theory dalam Perdagangan Seks di Tahiland, China dan Vietnam

(Yusnarida Eka Nizmi)

Terdapat figur pimpinan disetiap triad yang disebut dengan 'father" untuk mengawasi semua anggota dalam kegiatan illegal melalui sebuah hirarki (Macko, 1997). Triad secara umum terdiri dari beberapa kelompok independen; namun mereka bekerja dengan tujuan yang sama. Meskipun mereka terorganisir dengan sistem hirarki yang sama, namun mereka tidak berada dibawah rencana yang kaku dan pasti. Pola kerja mereka sangat tergantung pada situasi dilapangan.

\section{Jaringan Kriminal Thailand}

Thailand telah diidentifikasi sebagai negara sumber, transit dan negara tujuan bagi perdagangan seks. Sejak tahun 2001, Thailand diklasifikasikan pada negara Tier 2 atau Tier 2 Watch. Kelompok kejahatan terorganisir ini dipimpin oleh Jao Pho atau Godfather (Finckenauer and Chin, 2006). Sejak tahun 1960an, peningkatan industrialisasi dan urban di Thailand telah menimbulkan tatanan hukum yang baru yang justru diciptakan oleh kelompok sindikat kejahatan terorganisir. Jao Pho, merupakan sekelompok pebisnis yang turut andil dalam menciptakan berbagai aturan sesuai dengan kebutuhan dan kepentingan kelompoknya. Pada saat terjadi proses politik dan militer dalam membuat aturan dan perundang-undangan, Jao Pho akan memainkan perannya untuk mengamankan bisnisbisnis mereka termasuk perdagangan seks (Phongpaichit, 2004) dan hal ini terus berlangsung hingga saat ini.

Jao Pho adalah kelompok etnis China yang berbasis di berbagai propinsi di Thailand yang memiliki bisnis baik legal maupun bisnis kriminal. Mereka beroperasi secara independen dan metode operasi mereka juga seragam yakni: meningkatkan keuntungan dengan cara apapun dan membangun jaringan dengan pihak-pihak pemerintah yang dianggap memiliki peranan penting. Dapat dipastikan bahwa mereka beraliansi dengan para birokrat yang punya kedudukan tinggi, polisi, dan militer dan melakukan kesepakatankesepakatan "bawah meja" (Phongpaichit, 2004). Oleh karena itu penelitian-penelitian dalam bidang hukum kriminal menyatakan bahwa tanpa adalah upaya penegakan hukum untuk mengurangi perdagangan seks, maka aktivitas kriminal ini akan terus berlanjut.

Prostitusi adalah hal vital bagi industri pariwisata Thailand dan korupsi ditubuh pemerintah dibantu dengan kemampuan kelompok Jao Pho mengimport perempuanperempuan dari Asia Tenggara, terutama dari Burma ke Thailand kemudian lanjut ke Amerika Serikat. Dikarenakan kuatnya jaringan mereka, kelompok Jao Pho tidak hanya memperdagangkan kaum perempuan dan anak-anak, mereka juga menjalankan bisnis rumah bordil, dan mengontrol secara ketat keseluruhan operasi rumah-rumah bordil tersebut. Untuk menghindari deteksi dari aparat hukum, perempuan-perempuan ini, khususnya yang dikirim ke Amerika Serikat, biasanya ditempatkan terlebih dahulu dibeberapa lokasi untuk beberapa minggu. Harus diketahui bahwa pada dasarnya pemerintah Thailand juga berusaha untuk mengurangi perdagangan seks, terbukti dengan 
Vol 6, No 1, April 2011: $33-45$

adanya penanganan terhadap sekitar 150 kasus perdagangan seks antara Juli 2005 dan Juni 2007. Pemerintah Thailand juga melanjutkan upayanya dengan program-program kewaspadaan publik terhadap industri wisata seks illegal.

\section{Geng Vietnam}

Vietnam diidentifikasi sebagai negara asal, transit, dan negara tujuan perdagangan seks. Sejak tahun 2002, Vietnam dikelompokkan pada kelompok negara Tier 2 atau Tier 2 Watch. Jatuhnya Saigon pada tahun 1975, yang ditandai dengan berakhirnya perang Vietnam, membuat arus pengungsi Vietnam ke Amerika Serikat melonjak tajam. Geng-geng yang berasal dari Vietnam juga beroperasi di Amerika Serikat. Berhadapan dengan budaya dan bahasa yang berbeda, nilai-nilai yang bertentangan dengan keluarga dan lingkungan mereka, membuat banyak remaja Vietnam yang berada di Amerika Serikat bergabung dengan geng-geng untuk mendapatkan pengakuan dan uang melalui aktivitas obat dan seks (Long, 1997). Meskipun operasi geng Vietnam ini belum bisa dibandingkan dengan Triad China, geng-geng Vietnam ini juga terkenal dengan kekejamannya dalam mengintimidasi para korbannya.

Berbeda dengan Triad China, tidak ada geng yang dominan baik yang beroperasi di Vietnam maupun di Amerika Serikat. Secara umum, geng-geng ini memiliki karakteristik tertentu. Pertama, mereka memiliki mobilitas yang tinggi. Oleh karena itu, mereka biasanya mendirikan "rumah aman" disetiap wilayah dimana mereka melakukan perjalanan (Long, 1997). Kedua, mereka tidak ragu-ragu mengirimkan pesan untuk melakukan pembunuhan sadis terhadap para korbannya. Patut dicatat bahwa beberapa kelompok, seperti BTK (Born to Kill) yang berbasis di New York, memiliki struktur dan hirarki yang dipublikasikan sementara geng-geng lain biasanya justru tidak diketahui struktru resminya dan terbiasa merubah affiliasinya.

Vietnam memiliki tingkat kemiskinan yangt tinggi, dan ini menyebabkan geng-geng Vietnam dapat dengan mudah membujuk kaum perempuan dari daerah miskin dengan tawaran pekerjaan di luar Vietnam, membuat janji-janji pekerjaan palsu seperti pelayan, pengasuh bayi, model, dan pekerja pabrik dengan gaji tinggi dan kondisi kerja yang baik (Richard, 2000). Para perekrut membebankan biaya dokumen, transportasi kepada perempuan-perempuan dan anak-anak yang direkrut sebesar $\$ 25,000$ hingga $\$ 30,000$. Sekali direkrut, passport mereka akan ditahan, dan pergerakan mereka juga diawasi, dan banyak dari mereka dipaksa bekerja dalam prostitusi sampai hutang mereka terbayar.

Perempuan-perempuan ini sulit untuk keluar dari bisnis prostitusi karena adanya kekerasan, atau ancaman baik yang ditujukan ke diri mereka sendiri maupun keluarga mereka. Para korban perdagangan orang ini juga kerap mengalami siksaan fisik yang ekstrim dan siksaan mental melalui pemerkosaan, penahanan, dan aborsi. Geng-geng Vietnam berbuat sangat kasar sebagaiman yang dilakukan Triad China dalam merekrut dan 40 
menculik kaum perempuan dan anak-anak dan mentransport mereka ke "rumah aman" di negara lain sebelum dipindahkan ke Amerika Serikat. Perlu diketahui bahwa pusat-pusat penampungan bagi para korban telah dibangun, salah satunya di Hanoi dan kampanye kewaspadaan publik juga dilakukan untuk memberikan informasi kepada masyarakat mengenai bahaya perdagangan seks.

\section{Para Korban- Target}

Beberapa faktor yang berkontribusi terhadap sisi rentannya para perempuan menjadi target perdagangan seks, antara lain kemiskinan, dan bias gender.

\section{Kemiskinan}

Kemiskinan membantu kelancaran perbudakan seks. Pergerakan makro dari perbudakan seks melibatkan transit dari area-area dan negara-negara miskin ke area-area dan negara-negara kaya. Trafficking secara umum berasal dari tempat yang kesulitan ekonomi dan sosial, sehingga menyebabkan migrasi menjadi pilihan yang popular. Perdagangan seks di Asia Timur berasal dari daerah miskin Mekong subregion dari Burma, Kamboja, Laos dan Vietnam. Para perempuan sering direkrut oleh orang asing yang menjanjikan gaji yang tinggi dengan bekerja di luar negeri. Banyak di antara mereka yang menerima tawaran tersebut bahkan tidak mendapatkan gaji sama sekali dan dipaksa untuk terus bekerja karena terlibat utang.

Terlepas dari rasa putus asa, beberapa orang tua di Vietnam dan Thailand kadangkadang menjual satu atau dua anaknya kepada seseorang yang menjanjikan pekerjaan dengan tawaran gaji yang lumayan tinggi (UNICEF, 2005:10). Anak-anak menjadi sangat rentan terhadap penyelundupan dan perdagangan orang. Kondisi yang sama dengan kemiskinan, keputusasaan dan ketiadaan pekerjaan menggiring banyak keluarga untuk menjual anak pada industri pelacuran. Penjualan seperti itu merupakan keputusan yang sangat ekstrim. Penjual budak menawarkan pekerjaan pada orang tua sebagai alat tukar seorang anak. Dalam beberapa kasus, terdapat orang tua menjual anak karena tamak akan uang. Para orang tua ini menjadi terbiasa menjual anaknya untuk mendapatkan imbalan uang.

Kemiskinan membuat wanita lebih rentan terhadap eksploitasi, kekerasan, diskriminasi dan pengabaian hak-hak dasar sebagai manusia. Dengan kata lain, kemiskinan dan eksploitasi perempuan mengabaikan wanita secara keseluruhan. Keberadaan konvensikonvensi internasional dan hukum melawan pelacuran, juga cenderung memandang perempuan sebagai pekerja seks dibanding sebagai korban.

\section{Bias gender}

Perasaan tidak berguna sebagai perempuan menjadi pemicu tertinggi para penjual perempuan dalam memakmurkan perdagangan seks. Rasa putus asa untuk lari dari tirani seperti ini mengantarkan kaum perempuan India pada para penjual perempuan. Lebih 
Vol 6, No 1, April 2011: $33-45$

daripada persoalan kemiskinan, konflik militer, atau bencana-bencana sosial lainnya, pada dasarnya, yang menggiring perempuan jatuh pada perdagangan seks adalah eksploitasi.

Pada daerah-daerah yang kerap terjadi penyimpangan-penyimpangan seperti tersebut di atas, maka, perdagangan orang menjadi pekerja seks menjadi aktivitas yang mudah dijumpai. Perasaan ingin bebas dari segala siksaan dan diskriminasi menggiring perempuan jatuh pada lingkaran perdagangan seks yang mengikat hidup mereka. Cara sederhana untuk menghentikan perdagangan seks adalah dengan menerapkan hak asasi manusia seutuhnya yang menegaskan jika pria dan wanita mendapatkan hak yang sama. Pada akhirnya, tidak akan ada lagi perempuan-perempuan yang putus asa karena adanya bias gender di seluruh dunia.

Perdagangan seks merupakan perbudakan era modern (Gonzales, 2006). Diperkirakan 600,000 sampai 800,000 orang diperdagangkan setiap tahunnya. Lebih dari 80 persen dari para korban ini adalah kaum perempuan, dan 70 persen dari mereka dipaksa melakukan pekerjaan seks. Lebih lanjut, diperkirakan bahwa 14,500 dan 17, 500 korban diperdagankan ke Amerika Serikat setiap tahunnya. Namun sayangnya, di Asia Timur, karena tingkat kemiskinan sangat tinggi, gadis-gadis muda sangat potensial diekspor ke negara-negara industri seperti Amerika Serikat dimana industri seks menjadi bisnis favorit.

Beberapa daerah perbatasan juga memberi ruang yang begitu besar terhadap perdagangan seks. Terutama sejak perdagangan seks berhubungan dengan sindikat kejahatan terorganisir, para korban perdagangan orang secara umum tidak mencoba mencari pertolongan kepada pihak yang berwenang. Karena minimnya pemahaman para korban mengenai sistem hukum di Amerika, maka para korban perdagangan orang terpaksa bekerjasama dengan kelompok sindikat tersebut untuk menghindari deportasi dan penahanan. Kebanyakan para korban juga tidak percaya terhadap aparat pemerintah Amerika Serikat dikarenakan adanya pemahaman bahwa aparat pemerintah di negara mereka sering melakukan korupsi dan pemerasan terhadap para korban perdagangan orang. Para pelaku perdagangan orang, sering memindahkan para korbannya setiap 15 atau 30 hari dan membatasi kontak dengan dunia luar, sehingga para korban tidak memiliki kemampuan untuk membangun kehidupan sosialnya di luar dan melarikan diri.

\section{Minimnya Pengawal- Hukum}

Persoalan terbesar yang dihadapi banyak negara dalam melawan perdagangan seks adalah korupsi di tubuh pemerintahan, persoalan hukum, dan penerapan hukum. Lemahnya keinginan menerapkan hukum melawan perdagangan orang dan pelacuran menyebabkan jumlah kejahatan perdagangan orang untuk tujuan seks komersial terus meningkat tiap tahunnya. Selain penderitaan ratusan ribu korban perdagangan orang yang terus bertambah, negara-negara yang mengalami persoalan perdagangan seks juga sedikit sekali melakukan penanganan terhadap persoalan tersebut. 
Analisa Routine Activity Theory dalam Perdagangan Seks di Tahiland, China dan Vietnam

(Yusnarida Eka Nizmi)

Persoalan lemahnya penegakan hukum dalam melawan perdagangan seks dapat disebabkan karena perdagangan seks tidak dianggap sebagai persoalan serius (Iselin, 2002, 65). Dan di banyak negara Asia ini terjadi karena tiga alasan utama: Pertama, korupsi adalah faktor yang menggiring pada maraknya perdagangan seks. Kejahatan yang terorganisir, dengan keuntungan yang luar biasa, mampu menyuap pejabat-pejabat pemerintah untuk melengkapi dokumen, termasuk passport dan menghindari deteksi dari pihak-pihak yang berwenang. Kedua, di beberapa negara termasuk Thailand, peningkatan laju industri seks trafficking memberi keuntungan yang tidak sedikit pada pendapatan negara. Faktanya, Thailand bahkan merancang draft untuk melegalkan zona-zona prostitusi. Ketiga, perdagangan seks tidak diperlakukan layaknya kejahatan sebagaimana umumnya, seperti pembunuhan atau perampokan, sehingga pihak kepolisian pun tidak diberi target untuk mengurangi laju korban perdagangan seks. Terakhir, banyak budaya Asia, ada budaya yang secara normatif relatif membedakan perlakuan antara laki-laki dan perempuan, pola perlakuan terhadap anak, khususnya perempuan.

\section{KESIMPULAN}

Perdagangan seks adalah fenomena global yang tidak mengenal batas negara. Menyadari konsekwensi serius terhadap sisi kemanusiaan, pada tahun 2002, pemerintah Amerika Serikat menghabiskan biaya $\$ 25$ juta di masing-masing 50 negara untuk pelaksanaan program anti-perdangangan orang. Program-program ini dirancang untuk membantu NGO, organisasi-organisasi internasional, aparat penegak hukum, pemerintah luar negeri untuk mencegah terjadinya perdagangan orang, dan merehabilitasi para korban untuk kembali pada kehidupan normalnya. Dengan memberikan pendidikan pada masayarakat mengenai beragam program yang dirancang untuk melindungi para korban sesuai dengan Trafficking Victims Protection Act of 2000.

Tiga geng utama yang didiskusikan pada bab ini memaparkan taktik yang umum dipakai dalam memperdagangkan para korban mereka-mereka menemukan cara untuk mengeksploitasi "celah-celah" dalam hukum immigrasi AS untuk mengirim para korbanyya ke Amerika Serikat. Sebagai contoh, perempuan asing dan anak-anak dapat memasuki AS secara legal sebagai pelajar, wisatawan, pekerja domestik, ataupun calon pengantin. Lebih lanjut, tanggungjawab seperti rekrutmen, dokumen, transportasi justru tidak menjadi perhatian. Sebagai contoh, seorang perempuan dari satu negara terlibat dalam perdagangan orang mungkin tertarik dari iklan mengenai tawaran pekerjaan yang terkesan legal. Para pelaku perdagangan orang secara rutin memakai jasa kelompok jaringan penyeludupan orang yang dikenal sebagai "snakeheads", yang bertugas menjaring para korban ke Amerika Serikat melalui jalur laut dan udara. Beberapa geng mengenakan biaya sebesar $\$ 40,000$ pada para korban untuk tiket masuk ke Amerika Serikat. 
Sebagai konsekwensinya, banyak dari para korban perdagangan orang terjebak pada perbudakan era modern sebagai pekerja seks selama beberapa tahun sebelum pada akhirnya mereka dilepaskan, jika beruntung. Persoalan tragedi kemanusiaan ini dapat dijelaskan dengan teori Routine Activity yang memiliki tiga komponen. Motivasi Pihak penyerang, yakni besarnya keuntungan dari pasar perdagangan seks yang dijalankan oleh geng-geng Asia; Target yang sesuai, kaum perempuan yang dengan mudahnya direkrut terutama dari wilayah negara-negara yang secara ekonomi sangat kekurangan; dan Minimnya Pengawasan, sikap "tidak perduli" baik dari negara-negara Asia maupun Amerika Serikat. Meskipun masing-masing geng Asia secara struktur dan metode dalam menjaring para korbannya bervariasi, namun metode dalam mengirim para korbannya ke Amerika Serikat adalah sama. Keterlibatan sindikat kejahatan terorganisir Asia dalam perdagangan seks merupakan tantangan khusus bagi penegakan hukum di Amerika Serikat.

\section{DAFTAR PUSTAKA}

Assessment of U.S. Activities to Combat Trafficking in Persons. 2003. Washington, DC : U.S. Department of Justice, National Institute of Justice.

Clawson, H. J., Dutch, N., and Cummings, M., 2006. Law Enforcement Response to Human Trafficking and the Implications for Victims: Current Practices and Lesson Learned. Washington, DC: U.S. Department of Justice, National Institute of Justice.

Currant, D.J., and Renzetti, C. M., 2001. Theories of Crime (2nd ed). Boston : Allyn and Bacon.

Finckenauer, J. O., and Chin, K., 2006. Asian Transnational Organized Crime and Its Impact on the United States: Developing a Transnational Crime Research Agenda. Washington, DC: U.S. Department of Justice, National Institute of Justice.

Gonzale, A., 2006. Attorney General's Annual Report to Congress on U.S. Government Activities to Combat Trafficking in Persons Fiscal Year 2005. Washington, DC: Federal Research Division, Library of Congress.

Helfand, N.S., 2003. Asian Organized Crime and Terrorist Activity in Canada, 1999- 2002.

Innocenti Research Centre., 2005. Trafficking for Sexual Exploitation Purposes. United Nations Children's Fund. www. Unicef- icdc.org/publications/pdf/traffickingexploitation- eng.pdf.

Iselin, B., 2002. Barriers to Effective Human Trafficking Enforcment in the Mekong SubRegion. United Nations' Office on Drugs and Crime.

Kwong, Peter., 2001. Global Human Smuggling: Comparative Perspectives, Baltimore, MD: John Hopkins University

Long, P. (with Richard, L.)., 1997. The Dream Shattered: Vietnamese Gangs in America. Boston: Northeastern University Press.

Macko, S., 1997. Chinese Triads; an Update. Emergency Service Reports: Chicago, Illinois.

Marshall, P., and Thatun, S., 1998. Training Manual for Combating Trafficking in Women and Children. UN- Interagency Project on Combating Trafficking in Women and Children in the Sub- Mekong Region.

May, M., 2006. A youthful Mistake. San Fransisco Chronicle, p. 2 
Analisa Routine Activity Theory dalam Perdagangan Seks di Tahiland, China dan Vietnam

(Yusnarida Eka Nizmi)

McCabe, K., 2008. The Trafficking of Persons: National and International Responses. NY: Peter Lang.

2007. "Spousal Prostitution." In N. Jackson's Encyclopedia of Domestic Violance, pp. 673-674. NY: Routledge.

Osborne, D., 2006. Out of Bonds: Innovation in law Enforcement Intelligence Analysis. Washington, DC: Joint Military Intelligence College.

Peterson, M., 2005. Intelligence - Led Policing: the New Intelligence Architecture. Washington, DC: Bureau of Justice Assistance.

Phongpaichit, P., 2004. Thailand Under Thaksin: Another Malaysia? National Library of Australia: Working Paper No. 109.

Richard, A. O., 2000. International Trafficking in Women to the United States: A Contemporary Manifestation of Slavery and Organized Crime. State Department's Bureau of Intelligence and Research.

Song, J., and Dombrink, J., 1994. Asian Emerging Crime Groups: Examining the Definition of Organized Crime. Criminal Justice Review, 19 (2)

United Nations Office on Drugs and Narcotics (UNODC)., 2006. Trafficking in Persons: Global Patterns. UN: Human Trafficking Unit.

United States Department of State., 2007. Trafficking in Persons. Washington, DC : United States Department of State. 